\title{
Influence of Culture Media on Growth, Colony Character and Sporulation of Chaetomium globosum Fungus
}

\author{
K. W. Uikey ${ }^{*}$, K. S. Raghuwanshi and D. W. Uikey \\ Department of Plant Pathology and Agricultural Microbiology, PGI, M.P.K.V., \\ Rahuri, Maharashtra, India \\ *Corresponding author
}

\section{A B S T R A C T}

Ke y w o r d s
Mycelial growth,
Colony character,
Sporulation, Culture
media

The mycelial growth rate, colony character and sporulation pattern of Chaetomium globosum, grown on seven different culture media viz., Potato Dextrose Agar (PDA), Czapek's Dox media, Yeast Extract Agar, Sabouraud media, Oatmeal Agar, Malt Extract Agar and Lignocellulose Agar (LCA) were observed after seven days of incubation at $25 \pm 1^{\circ} \mathrm{C}$. The colony diameter, culture characteristics and sporulation of Chaetomium globosum were greatly influenced by the type of growth medium used. Sabouraud medium exhibited comparatively higher mycelial growth of Chaetomium globosum, followed by Potato Dextrose and lignocelluloses agar medium. With regard to sporulation, excellent sporulation was observed on sabouraud medium. Poor sporulation was observed on malt extract agar. These results will be useful for fungal taxonomic studies.

\section{Introduction}

Fungi grow on diverse habitats in nature and are cosmopolitan in distribution requiring several specific elements for growth and reproduction. In laboratory, these are isolated on specific culture medium for cultivation, preservation, microscopical examination and biochemical and physiological characterization. A wide range of media are used for isolation of different groups of fungi that influence the vegetative growth and colony morphology, pigmentation and sporulation depending upon the composition of specific culture medium, $\mathrm{pH}$, temperature, light, water availability and surrounding atmospheric gas mixture (Northolt and Bullerman, 1982).

Different concepts have been used by the mycologists to characterize the fungal species, out of which morphological (phenetic 
or phenotypic) and reproductive stages are the classic approaches and baseline of fungal taxonomy and nomenclature that are still valid (Davis, 1995; Guarro et al., 1999; Diba et al., 2007; Zain et al., 2009). Physical and chemical factors have a pronounced effect on diagnostic characters of fungi.

Hence, it is often necessary to use several media while attempting to identify a fungus in culture since mycelial growth and sporulation on artificial media are important biological characteristics (St-Germain and Summerbell, 1996).

With these perspectives, the present study was undertaken to observe the influence of seven different culture media on the mycelial growth, colony characters and sporulation patterns of Chaetomium globosum.

\section{Materials and Methods}

\section{Collection of rhizosphere soil sample}

The fresh rhizosphere soil samples were obtained from various places from the field of M.P.K.V. Rahuri.

\section{Sterilization of glasswares and media}

The glasswares required for isolation of biocontrol agents and soil borne pathogens were sterilized in hot air oven at $160^{\circ} \mathrm{C}$ for two hours. The culture media for isolation of organisms were steam sterilized at $121.6^{\circ} \mathrm{C}$ (i.e. $151 \mathrm{bs}$ pressure / $\mathrm{inch}^{2}$ ) for 15 minutes.

\section{Isolation of Chaetomium globosum}

The soil samples were air dried, grinded and sieved through $0.50 \mathrm{~mm}$ sieve so as to obtain fine sized particles. The $10.0 \mathrm{~g}$ of rhizosphere soil samples were weighed on electronic balance and used for isolation purpose by serial dilution method.

\section{Purification and maintenance of pure culture}

The fungus growth that is obtained from the soil were purified by hyphal tip method and maintained on fresh potato dextrose agar medium slant under aseptic condition.

\section{Identification}

The fungus isolated from diseased specimen and established in pure form was tentatively identified on the basis of colony and morphological characters and observations were recorded with the help of research microscope.

\section{Preparation of different media for cultural studies of Chaetomium globosum fungus}

The seven cultures viz., 1) Potato dextrose agar medium 2) Oatmeal agar medium 3) Lignocellulose agar medium 4) Malt extract agar medium 5) Yeast extract agar medium 6) Sabouraud media 7) Czapek's Dox agar medium were prepared in conical flasks of $250 \mathrm{ml}$ capacity separately and taken in petri dish for isolation of Chaetomium by serial dilution method and pour plate method.

\section{Cultural characters}

The study of cultural characters of the fungus was undertaken with the object to see the growth behaviour and also to note its sporulating variability on different cultural media. For this purpose following cultural media were studied.

\section{Composition of different media}

Potato dextrose agar (PDA)

$\begin{array}{lc}\text { Potato (peeled) } & 200 \mathrm{~g} \\ \text { Dextrose } & 20 \mathrm{~g} \\ \text { Agar } & 20 \mathrm{~g} \\ \text { Distilled water } & 1000 \mathrm{ml}\end{array}$




\section{Czapek's dox agar (CDA)}

Sucrose

Sodium nitrate

Dipotassium hydrogen phosphate

Potassium chloride

Magnesium sulphate

Ferrous sulphate

Agar

Distilled water

Malt extract agar

Malt extract

$30.0 \mathrm{~g}$

Mycological peptone $5.0 \mathrm{~g}$

Agar

$15.0 \mathrm{~g}$

Distilled water

$1000 \mathrm{ml}$

\section{Oat meal agar medium}

1) Oatmeal

$30 \mathrm{~g}$

2) Agar agar

$20 \mathrm{~g}$

3) Distilled water

$1000 \mathrm{ml}$

\section{Yeast extract}

1) Yeast extract $3 \mathrm{~g}$

2) Peptone $5 \mathrm{~g}$

3) Agar agar $\quad 15 \mathrm{~g}$

4) Distilled water $1000 \mathrm{ml}$

\section{Lignocellulose media}

1) Glucose

2) Monopotassium phosphate

$1 \mathrm{~g}$

3) Magnesium sulphate

4) Potassium chloride

5) Sodium nitrate

6) Yeast extract

7) Agar agar

8) Distilled water

Sabouraud dextrose agar
1) Dextrose
$40 \mathrm{~g}$
2) Peptone
$10 \mathrm{~g}$
3) Agar agar
$15 \mathrm{~g}$
4) Distilled water
$1000 \mathrm{ml}$

$30 \mathrm{~g}$

$2 \mathrm{~g}$

$1 \mathrm{~g}$

$0.5 \mathrm{~g}$

$0.5 \mathrm{~g}$

$0.01 \mathrm{~g}$

$20 \mathrm{~g}$

$1000 \mathrm{ml}$
Thereafter, $5 \mathrm{~mm}$ discs of Chaetomium globosum fungus obtained from pure culture were transferred at the centre of sterile Petri dishes (in triplicates) containing seven different growth media viz., 1) Potato dextrose agar medium 2) Oatmeal agar medium 3) Lignocellulose agar medium 4) Malt extract agar medium 5) Yeast extract agar medium 6) Sabouraud media 7) Czapek's Dox agar medium. The Petri dishes were then incubated for 7 days at $25 \pm 1{ }^{\circ} \mathrm{C}$ in BOD incubator and colony character of Chaetomium globosum fungus was recorded. Sporulation was assessed on haemocytometer glass slides by mounting a small portion of mycelia and observed under microscope.

\section{Results and Discussion}

\section{Cultural characters of Chaetomium globosum on different medium}

The colony diameter, sporulation and growth characters of Chaetomium globosum on seven different media were studied and the results are represented in (Table 1, Fig. 1) which revealed that the effect of different media on growth and sporulation of Chaetomium globosum was significant.

Significantly maximum growth was observed on sabouraud medium $(90 \mathrm{~mm})$ because glucose or maltose and peptone were the most suitable carbon and nitrogen source for Chaetomium growth followed by PDA (63 $\mathrm{mm}$ ), while minimum growth was observed on Czapek's dox agar medium. As regards the sporulation (Table 1, Fig. 1), highly sporulation was observed on sabouraud medium $\left(11.60 \times 10^{4}\right)$. Moderate sporulation was observed on Potato dextrose agar (10.80 $\left.\times 10^{4}\right)$ and lignocellulose medium $\left(9 \times 10^{4}\right)$ and poor sporulation was observed on malt extract agar $\left(5.00 \times 10^{4}\right)$. 
Table.1 Performance of Chaetomium under different culture medium

\begin{tabular}{|c|c|c|c|c|}
\hline $\begin{array}{l}\text { Sr. } \\
\text { No. }\end{array}$ & Media & $\begin{array}{l}\text { Mean Growth } \\
(\mathrm{mm})\end{array}$ & $\begin{array}{c}\text { Mean Spore } \\
\text { Count } \times\left(10^{4}\right)\end{array}$ & Growth characters \\
\hline 1 & Sabouraud media & 90.00 & 11.60 & $\begin{array}{l}\text { Very restricted, irregular } \\
\text { growth, dark gray to brown in } \\
\text { colour }\end{array}$ \\
\hline 2 & Oatmeal agar & 20.00 & 6.40 & $\begin{array}{l}\text { Restricted, irregular growth, } \\
\text { Golden brown to yellow in } \\
\text { colour }\end{array}$ \\
\hline 3 & $\begin{array}{l}\text { Czapek's dox agar } \\
\text { media }\end{array}$ & 15.00 & 6.60 & $\begin{array}{l}\text { Very restricted, irregular } \\
\text { growth, Golden brown to } \\
\text { yellow in colour }\end{array}$ \\
\hline 4 & $\begin{array}{l}\text { Yeast extract } \\
\text { agar }\end{array}$ & 35.00 & 8.60 & $\begin{array}{l}\text { Restricted, circular to } \\
\text { irregular growth, Golden } \\
\text { brown to yellow in colour }\end{array}$ \\
\hline 5 & $\begin{array}{l}\text { Lignocellulose } \\
\text { media }\end{array}$ & 45.00 & 9.00 & $\begin{array}{l}\text { Very restricted, irregular } \\
\text { growth, Light greenish } \\
\text { yellow in colour }\end{array}$ \\
\hline 6 & Malt extract & 22.33 & 5.00 & $\begin{array}{l}\text { Very restricted, circular to } \\
\text { irregular growth, orange gray } \\
\text { in colour }\end{array}$ \\
\hline 7 & $\begin{array}{l}\text { Potato Dextrose } \\
\text { agar }\end{array}$ & 63.00 & 10.80 & $\begin{array}{l}\text { Restricted, circular to } \\
\text { irregular growth, Velvety } \\
\text { Light Yellow in colour }\end{array}$ \\
\hline 8 & $\mathrm{SE}( \pm)$ & 1.51 & 0.23 & _ \\
\hline 9 & CD @ 5\% & 4.67 & 0.67 & _- \\
\hline
\end{tabular}

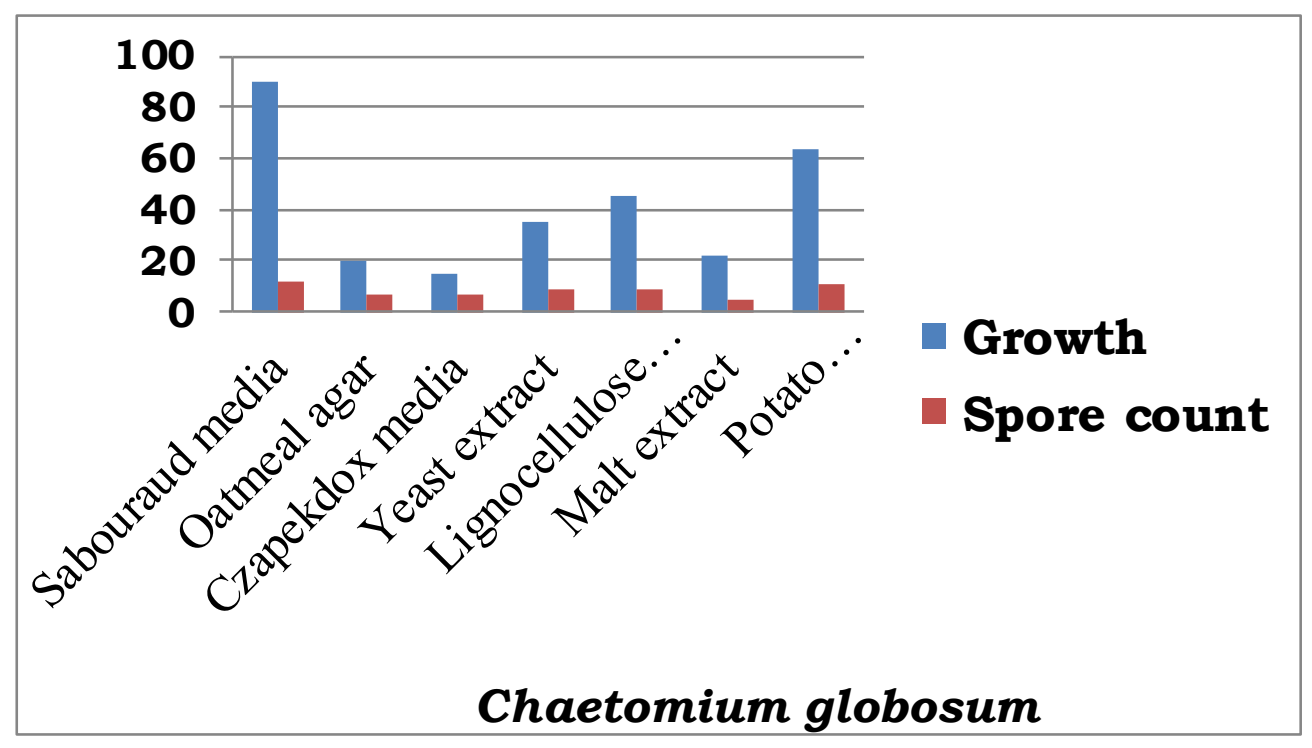

Fig.1 Performance of Chaetomium globosum under different culture medium 


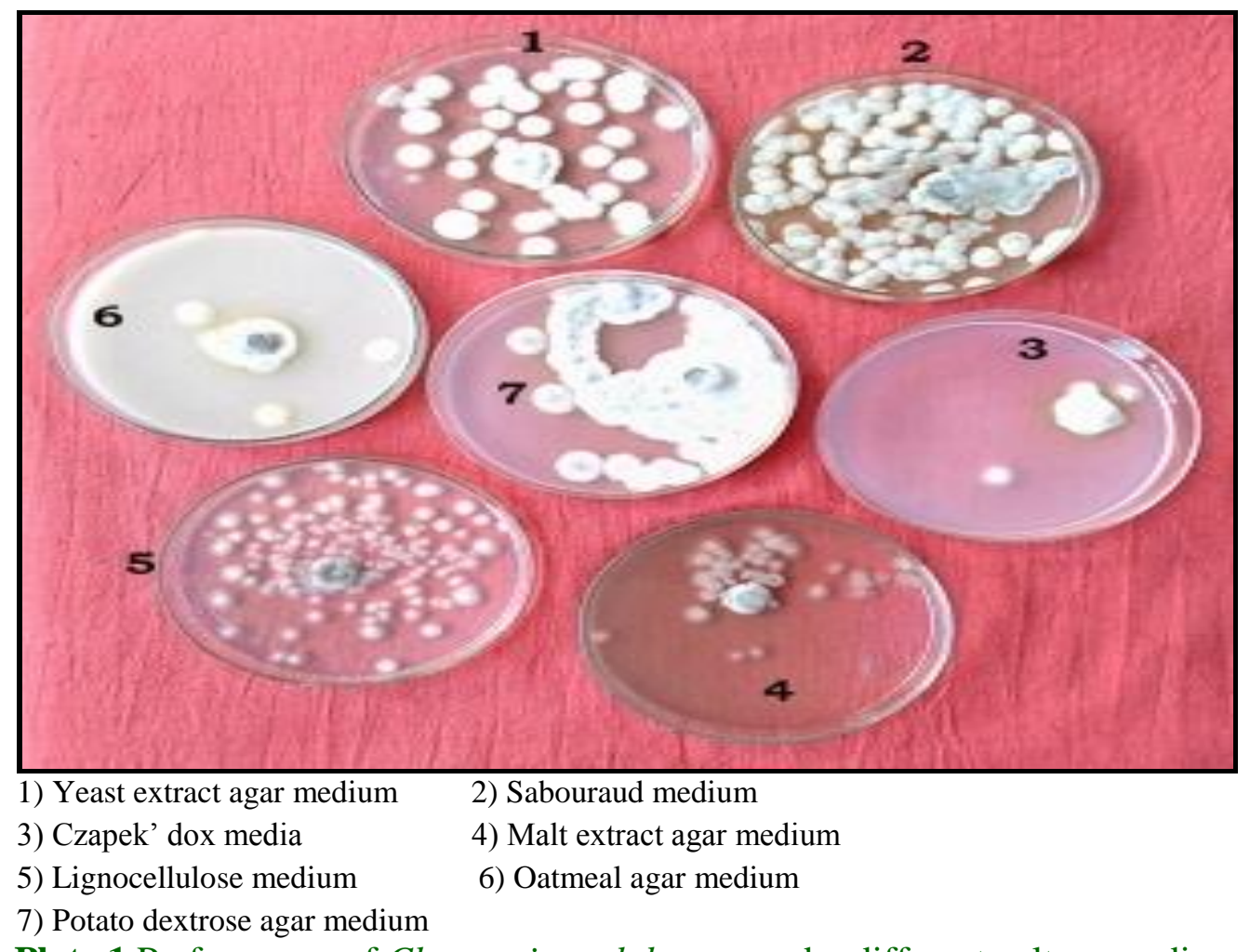

While studying the cultural characters, it was observed that the fungus produced maximum growth on sabouraud medium followed by potato dextrose agar and lignocelluloses agar medium. With regard to sporulation, excellent sporulation was observed on sabouraud medium. Poor sporulation was observed on malt extract agar.

The results obtained in this study is not confirmed with the results given by Matthew et al., (2008) and Sharma et al., (2010) who studied colony diameters of $C$. globosum over 4 weeks on different agar media viz., potato dextrose agar (PDA), oatmeal agar (OA), cornmeal agar (CMA) and malt extract agar (MEA) and found that oatmeal agar exhibited comparatively higher myclial growth and sporulation.

Our findings revealed that culture media differentially influenced the growth, colony character and sporulation of Chaetomium globosum.
Out of seven test media employed in the present study, Sabouraud media was found to be most suitable for heavy growth and sporulation followed by PDA.

\section{References}

Bustohn, W. and Rickard. 1956. The Effect of a physical barrier on sporulation of Chaetomium globosum. J. gen. Microbiol. Vol. 15, 194-197.

Chatterji, B.C. 1966. Some observations on the growth and sporulation of Chaetomium globosum in media containing ammonium tartrate. Transactions of the British Mycological Society. 49 (3) Pages 397-401.

Davis JI (1995). Species concepts and phylogenetic analysis. Introduction. Syst. Bot., 20: 555-559.

Diba K, Kordbacheh P, Mirhendi SH, Rezaie S, Mahmoudi M (2007).Identification of Aspergillus species using morphological characteristics. Pak. J. Med. Sci., 23(6): 
867-872.

Domsch, K.H., Gams, W. and Anderson, T.H. 2007. Compendium of soil fungi. 2nd ed. Munchen: IHW Verlag. 672 p.

Guarro J, Josepa G, Stchigel AM (1999). Developments in Fungal Taxonomy. Clin. Microbiol. Rev., 12: 454-500.

Matthew, R., Fogle, D.R., and Straus, D.C. 2008. Growth and mycotoxin production by Chaetomium globosum is favoured in a neutral $\mathrm{pH}$. Int. J. Mol. Sci. Vol. 9, 2357-2365.

Northolt MD, Bullerman LB (1982). Prevention of mold growth and toxin production through control of environmental condition. J. Food Prot., 6: 519-526.

Sharma, G. and Pandey, R.R. 2010. Influence of culture media on growth, colony character and sporulation of fungi isolated from decaying vegetable wastes. J. Yeast Fungal Res. Vol. 1(8), pp. 157-164.

St-Germain G, Summerbell R (1996). Identifying Filamentous Fungi - A Clinical Laboratory Handbook, 1st Ed. Star Publishing Co., Belmont, California. UKNCC (1998). Growth and Media Manuals. Strain databases (www.ukncc.co.uk/)

Zain ME, Razak AA, El-Sheikh HH, Soliman HG, Khalil AM (2009). Influence of growth medium on diagnostic characters of Aspergillus and Penicillium species. Afr. J. Microbiol. Res., 3(5): 280-286.

Zayat, S.A. 2008. Preliminary studies on laccase production by Chaetomium globosum an endophytic fungus in Glinus lotoide, American-Eurasian I. Agric. \& Environ Sci. 3 (1): ISSN 18: 18-6769, 86-90.

\section{How to cite this article:}

Uikey, K. W., K. S. Raghuwanshi and Uikey, D. W. 2020. Influence of Culture Media on Growth, Colony Character and Sporulation of Chaetomium globosum Fungus. Int.J.Curr.Microbiol.App.Sci. 9(05): 2567-2572. doi: https://doi.org/10.20546/ijcmas.2020.905.293 